\title{
Indonesian Islamic socialism and its South Asian roots
}

\author{
Kevin W. Fogg, Oxford Centre for Islamic Studies, Oxford, UK, \\ kevin.fogg@ history.ox.ac.uk ${ }^{1}$
}

\begin{abstract}
Islamic socialism was a major intellectual and political movement in Indonesia in the twentieth century, with ongoing influences until today. However, this movement did not follow the most common narratives of Indonesian intellectual history, which trace religious influences to the Middle East and political movements to anti-colonial reaction in terms framed by the Dutch. Rather, the first major Indonesian proponent of Islamic socialism, H. O. S. Tjokroaminoto, took his thinking on Islamic socialism directly from the English-language work of a South Asian itinerant scholar, Mushir Hosein Kidwai, in a process that most likely had the minority Ahmadiyyah community as intermediaries. Future Islamic socialist thought, much of it influenced by Tjokroaminoto, continued to echo through Indonesian secular nationalism, political Islam, and even Islamism. Studying the intellectual origins of Islamic socialism in Indonesia, then, shows not only the roots of an important strand of Southeast Asian politics in the last century, but also the importance of alternative currents of thought (South Asian, outside the mainstream, Anglophone) in Southeast Asian Islam.
\end{abstract}

\section{Introduction}

As nationalist movements broke out across Southeast Asia in the first half of the twentieth century, religion and socialism were very common inspirations. Religion inspired discussions, debates, and organizations leading to anti-colonial resistance and an alternative vision for organizing collective life, be it Buddhism in Burma, Cambodia and Vietnam; ${ }^{2}$ Catholicism in the Philippines and Vietnam; ${ }^{3}$ or Islam in Indonesia and Malaysia. ${ }^{4}$ At the same time, and usually in rivalry with these religious nationalisms, socialism was spreading throughout Asia, sometimes locally grown and sometimes emanating from foreign activists. ${ }^{5}$

In Indonesia in particular, religious renewal and socialism as intellectual movements were not only influential individually, but they came together in the trend of Islamic socialism. In the country's first nationwide election in 1955, some $27 \%$ of the vote went to self-professed Islamic socialist parties (in both the Partai Masjumi and the Partai Sarekat Islam Indonesia). ${ }^{6}$ The legacy of Islamic socialism has been crucial for the development of both Islamic parties and non-Islamic parties, including the Indonesian Socialist Party, the Indonesian Communist Party, the Murba or Proletariat Party, Parkindo or the Christian Party, the Indonesian National

\footnotetext{
${ }^{1}$ The author would like to thank Faizah Zakaria, Syahrul Hidayat, Rémy Madinier, Adeel Malik, Ibrahim Amin, Megan Robb, Fouzia Farooq, Francis Robinson, Michael Feener; audiences at the Annual International Conference of Islamic Studies in Mataram (2013), Universitas Darussalam-Gontor, the Yale Council on Southeast Asia Studies, Metropolitan University Prague, and the Oxford Centre for Islamic Studies; and the two anonymous reviewers for their contributions to improving this paper. All faults remain with the author.

2 M. J. Walton, Buddhism, Politics, and Political Thought in Myanmar, Cambridge, Cambridge University Press, 2016, chapter 2; A. Turner, Saving Buddhism: The Impermanence of Religion in Colonial Burma, Honolulu, University of Hawai'i Press, 2014; Maung Maung, From Sangha to Laity: Nationalist Movements of Burma, 1920- 1940, New Delhi, Manohar, 1980; A. R. Hansen, How to Behave: Buddhism and Modernity in Colonial Cambodia, 1860-1930, Honolulu, University of Hawai'i Press, 2007; S. F. McHale, Print and Power: Confucianism, Communism, and Buddhism in the Making of Modern Vietnam, Honolulu, University of Hawai'i Press, 2004, chapter 5.

${ }^{3}$ C. Keith, Catholic Vietnam: A Church from Empire to Nation, Berkeley, University of California Press, 2012; F. von der Mehden, Religion and Nationalism in Southeast Asia: Burma, Indonesia, the Philippines, Madison, University of Wisconsin Press, 1963.

${ }^{4}$ M. F. Laffan, Islamic Nationhood and Colonial Indonesia: The Umma Below the Winds, London, Routledge, 2003; C. S. Kessler, Islam and Politics in a Malay State: Kelantan, 1838-1969, Ithaca, Cornell University Press, 1978.

${ }^{5}$ McHale, chapter 4; R. T. McVey, The Rise of Indonesian Communism, Ithaca, Cornell University Press, 1965; Kim Khan Huynh, Vietnamese Communism, 1925-1945, Ithaca, Cornell University Press, 1982.

${ }^{6}$ Alfian, Hasil Pemilihan Umum 1955 untuk Dewan Perwakilan Rakjat (D.P.R.), Jakarta, LEKNAS, 1971.
} 
Party, and successor parties down to Islamic parties of today and the Gerindra, which was a strong force in the 2014 parliamentary and presidential elections. ${ }^{7}$ Although Islamic socialism had some impact elsewhere in Southeast Asia, for example in the Partai Islam Se-Malaysia from 1956 to 1965 under Burhanuddin al-Helmy, even this was strongly influenced by the model of Indonesian Islamic socialists of the early twentieth century. ${ }^{8}$

Although a diverse array of Muslims have affiliated themselves with socialist or leftist movements, not all of these are the sort of Islamic socialism on which this article focuses. For the purposes of this article, "Islamic socialism" is a political and economic ideology that derives from Islamic teachings to reach socialist conclusions, such as protecting the poor, promoting equality, holding capitalism in check, and nationalizing certain key industries.

The roots of this tradition of Islamic socialism are often traced to Abu Dhar al-Ghifari, a companion of the Prophet Muhammad, who promoted the equal distribution of wealth. ${ }^{9}$ Others have noted how key institutions of Islam, such as the requirement to provide alms to the poor and contribute to the community through zakat, facilitate socialist or social justice aims. ${ }^{10}$ Still, certain key hallmarks of Marxism, such as the redistribution of the means of production, were uniformly eschewed by Islamic socialism, which held the right to private property as a key element of religious teachings.

Many attempts to build socialism in the Muslim world have indeed not been based on Islamic ideals. In the early twentieth century, the South Asian groups called Islamic socialists or Muslim socialists were simply Marxists who happened to hail from Muslim backgrounds, such as the émigrés who founded the Indian Communist Party from Tashkent. ${ }^{11}$ In the Middle East, President Gamal Abdul Nasser of Egypt claimed his government's programme in the 1950s was "Islamic socialism," although Arabic Socialism or Egyptian socialism would have been equally appropriate names - the policies were not derived from Islam, despite some congruence with the religion. There were also Marxist parties in both Egypt and Syria, but they did not base their platforms on Islamic beliefs. ${ }^{12}$ Similarly, in South Asia after partition, Zulkifar Ali Bhutto called his policies "Islamic socialism," while really his platform was more "an amalgam of anti-Indianism, socialism and nationalism." 13

This article focuses instead on socialism built on the foundation of religious principles, with serious consideration of Islamic texts and theological issues. In the Arab world, this was represented in the twentieth century by scholars like Mustafa al-Siba' ${ }^{14}$ and several local

${ }^{7}$ G. Fealy and B. Platzdasch, 'The Masjumi legacy: between Islamist idealism and political exigency', Studia Islamika, vol. 12, no. 1, 2005, pp. 73-100. The Gerindra is run by Prabowo Subianto, whose father Sumitro Djojohadikusumo was a politician with the Indonesian Socialist Party in the 1950s and a close ally of the Islamic Socialists in Masjumi.

${ }^{8}$ F. A. Noor, The Malaysian Islamic Party PAS 1951-2013: Islamism in a Mottled Nation, Amsterdam, Amsterdam University Press, 2014, pp. 47-63.

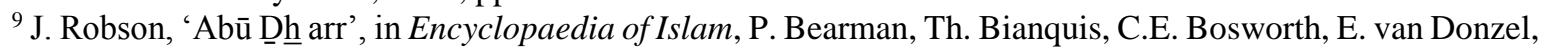
and W.P. Heinrichs (eds.), Leiden, Brill, 2012, http://referenceworks.brillonline.com/entries/encyclopaedia-ofislam-2/abu-dharr-SIM_0173 [accessed 1 January 2016]; A. Hasan, 'Social justice in Islam', Islamic Studies, vol. 10, no. 3, 1971, pp. 210-211.

${ }^{10}$ M. Rasjidi, Islam dan Socialisme, Jakarta, Jajasan Islam Studi Club Indonesia, 1966, pp. 60-70. Cf. M. Rodinson, 'Relationships between Islam and Communism', in Marxism and the Muslim world, London, Zed Press, 1979, pp. 34-59.

${ }^{11}$ On this group, see K.H. Ansari, 'Pan-Islam and the making of the early Indian Muslim Socialists', Modern Asian Studies, vol. 20, issue 3, July 1986, pp. 509-37.

12 M. Rodinson, 'Problems facing the Communist parties in Syria and Egypt' in Marxism and the Muslim world, London, Zed Press, 1979, pp. 60-75.

${ }^{13}$ B. M. Chengappa, 'Pakistan: Impact of Islamic Socialism', Strategic Analysis, vol. 26, no. 1, 2002, p. 27.

${ }^{14}$ An analysis of al-Siba'i and a translation of key points of his seminal work can be found in G. H. Gardner and S. A. Hanna, 'Islamic Socialism', The Muslim World, vol. 56, issue 2, April 1966, pp. 71-86. 
movements that were "deeply rooted rather than superficial, and Islamic rather than secular."15 In Iran, similarly, there was a strain of socialist individuals who derived their beliefs from religious thought, like Solaymān Mīrzā Eskandarī, ${ }^{16}$ although they were not as numerous or influential as the more materialist leftists in mid-century. ${ }^{17}$ Indonesia's case differs notably from the Middle East and South Asia, though, because of the wholesale imitation of the intellectual movement of an outside thinker.

When discussing Indonesia's Islamic intellectual history, scholars (especially Indonesian scholars) have focused in the past few decades on the intellectual influence of the Middle East on Indonesian Muslims, to the point where this is seen not only as the normative influence but even as the exclusive source of Islamic renewal. ${ }^{18}$ However, South Asia was also an important source of Islamic thought for Southeast Asia in the twentieth century. ${ }^{19}$ This alternative current was sometimes channelled directly (by Indonesian translations of South Asian thinkers), but at other times indirectly, as with scholarship published in Europe that was then read in Indonesia. This was the case for one particular South Asian thinker, Mushir Hosein Kidwai, who was influential for his thought on Islam and socialism. A work that Kidwai published in London came to influence the leading Indonesian nationalist H.O.S. Tjokroaminoto, whose work on Islamic socialism had a strong influence on Indonesian Islamic organizations and political life for the remainder of the century. The means by which Tjokroaminoto came to study Kidwai's work are especially interesting, and speak to the influence of yet another South Asian Islamic movement, the Ahmadiyyah, on Indonesia's intellectual development.

Studying the intellectual origins of Islamic socialism in Indonesia, then, shows not only the roots of an important strand of Southeast Asian political parties for the last century, but also the importance of alternative currents of thought (South Asian, outside the mainstream, Anglophone) in Southeast Asian Islam. The resulting intellectual trends continued to have an impact through secular nationalism, Islamic politics, and Islamism up until today.

\section{Islamic socialism of Mushir Hosein Kidwai}

The origins of modern Islamic socialist thought lay in the Islamic reformist movements that were shaking the Islamic world from the late nineteenth century. The spirit of Islamic reformism, which allowed for fresh interpretations from the scriptural sources of Islam, led to a wide range of intellectual movements. New interpretations allowed for pushing new social forms, not just socialism but also monogamy, for example. ${ }^{20}$ Although some scholars trace the

${ }^{15}$ O. El Shakry, " "History without documents": The vexed archives of decolonization in the Middle East', American Historical Review, vol. 120, no. 3, June 2015, p. 931, n. 55.

${ }^{16}$ Cosroe Chaqueri, 'Eskandarī, Solaymān (Moḥsen) Mīrzā', Encyclopaedia Iranica, Ehsan Yarshater et al. (eds.), http://www.iranicaonline.org/articles/eskandari-solayman-mohsen-mirza [accessed 2 May 2017].

${ }^{17} \mathrm{~F}$. Azimi, The quest for democracy in Iran: A century of struggle against authoritarian rule, Cambridge, Harvard University Press, 2008, pp. 127-131.

${ }^{18}$ For a normative indigenous view of the Middle East as the source for Islamic intellectual developments in twentieth century Indonesia, see K. W. Fogg (ed. and trans.), 'The influence of Muhammad Abduh in Indonesia: Speech given by Hamka (Haji Abdul Malik Karim Amrullah) when receiving a doctorate Honoris Causa from alAzhar University, Cairo', Afkaruna: Indonesian Interdisciplinary Journal of Islamic Studies, vol. 11, no. 2, December 2015, pp. 125-156. For a more recent case, see M. van Bruinessen, 'Ghazwul Fikri or Arabization? Indonesian Muslim responses to globalization', in Southeast Asian Muslims in the Era of Globalization, Ken Miichi and Omar Farouk (eds.), Basingstoke, Palgrave Macmillan, 2015, pp. 61-85.

${ }^{19}$ On an earlier era of South Asian influence on Southeast Asian Islam, see the special issue of Indonesia and the Malay World about 'Global conjunctions in the Indian Ocean - Malay world textual trajectories', vol. 41, no. 120 (July 2013). On the modern era, see R. M. Feener and T. Sevea (eds.), Islamic Connections: Muslim Societies in South and Southeast Asia, Singapore, Institute of Southeast Asian Studies, 2009.

${ }^{20}$ N. A. Jawed, 'Islamic Socialism: An ideological trend in Pakistan in the 1960s', The Muslim World, vol. 65, issue 3, July 1975, p. 207. 
roots of Islamic socialism in South Asia further back, for example to Shah Wali Allah, ${ }^{21}$ the explicit turn to the rhetoric of socialism, the formulation of large theoretical structures on this basis, and an awareness of non-religious socialist ideas came in the early twentieth century.

One of the first South Asian individuals to synthesize Islamic thinking into a formal call for socialism was Mushir Hosain Kidwai. He was born in India's United Provinces in 1878, but it was when he began travels and studies around the world that he made a real impact. Kidwai hailed from a noble family in north India that could trace its roots back to the companions of the Prophet. The Kidwai clan was large and powerful in Sufi and scholarly life, ${ }^{22}$ and Mushir Hosain Kidwai would have been educated in traditional Islamic schools before looking to the colonial metropole for further study.

In 1897, Kidwai moved to England to study for the bar, and he was admitted as a lawyer within several years. In 1904, he moved back to India to work in law, but he maintained active ties with the Muslim community of London and a strong interest in international Islamic issues, eventually returning to Britain in $1913 .{ }^{23}$ At that time, Mushir Hosain Kidwai was a leader in the Pan-Islamic Society, an organization of Muslims based in Britain who promoted solidarity among all Muslim peoples, anti-colonialism, and Islamic revivalism. Continuing the new wave of major works by Muslim authors written in European languages and the Western scholarly tradition, ${ }^{24}$ one of the major aspects of the Society's work was publishing on Islamic issues, and Kidwai was a prolific author in this effort. Between 1913 and 1920, he produced no less than eighteen pamphlets and books, ranging in topic from the role of women to comparative martyrdom among several religions to political issues in Turkey. ${ }^{25}$ By the end of his career, he was famous for his publications on the question of the Caliphate and self-rule for South Asians. ${ }^{26}$ His first book, though, was entitled Islam and Socialism.

Islam and Socialism was penned as Kidwai was preparing to return to England from India, and was published soon after his arrival in London. The epigraph of Kidwai's book summarizes his general position: "To us [Muslims], Socialism means an organized, continuous and harmonious co-operation of individuals in all the affairs of life, whether industrial or economic, administrative or political, social or religious, with a view to securing universal well-being and general prosperity. The more general, the more brotherly, and the more equally balanced that co-operation is, the better would be the constitution of Socialism." 27

Kidwai's arguments in favour of socialism built from Qur'anic sources and Islamic history to argue for socialism as a religious system. In particular, Kidwai tried to demonstrate socialism in the lives of the Prophet and his companions: "The key-note of Muhammad's Socialism was the spiritual and moral advancement of the people. His Socialism was ethical, while modern Socialism is materialistic." 28 Kidwai pulled from the Qur'an and the hadith very adeptly, building from the idea of common humanity to human dignity to the necessity of socialism and the practice of socialism during the early years of Islam.

${ }^{21}$ M. Al-Ghazali, The Socio-Political Thought of Shah Wali Allah, Islamabad, International Institute of Islamic Thought, 2001, p. 25; Jawed, p. 196; M. Al-Faruque, 'Some aspects of Islamic revivalist movements in India during the $18^{\text {th }}$ Century: The activities of Shah Wali-Allah of Delhi', Islamic Culture, vol. 63, no. 3, July 1989, p. 29.

${ }^{22}$ F. Robinson, lecture on 'Maulana Jamal Mian Farangi Mahalli and Pakistan', Oxford Centre for Islamic Studies, Oxford, 6 November 2013.

23 'Kidwai, Shaikh Mushir Husain (1878-1937)', in Muslims in India: A Biographical Dictionary, vol. II, N. K. Jain (ed.), New Delhi, Manohar, 1983, p. 22; S. T. Wasti, 'Mushir Hosain Kidwai and the Ottoman cause', Middle Eastern Studies, vol. 30, no. 2, 1994, p. 253.

${ }^{24}$ N. Green, 'Spacetime and the Muslim Journey West: Industrial Communications in the Making of the "Muslim World" ', American Historical Review, vol. 118, no. 2, April 2013, pp. 409-411.

${ }^{25}$ Wasti, 254.

26 'Kidwai, Shaikh Mushir Husain', p. 23.

${ }^{27}$ S. M. H. Kidwai, Islam and Socialism, London, Luzac \& Co., [1912], unnumbered copyright page.

${ }^{28}$ Kidwai, Islam and Socialism, p. v. 
At the same time, Kidwai's writing was very much grounded in the historical reality of Europe in the early twentieth century. He quoted from some socialist thinkers, and also a great many British orientalists. This was in line with his broader publishing activities in London, where he worked in the Islamic Information Bureau publishing pro-Turkish literature alongside the likes of Marmaduke Pickthall, the famous convert and Qur'an translator. ${ }^{29}$ To complete his argument, and to demonstrate the modernity of certain sectors of the Islamic world, Kidwai also referred to events in the Middle East, especially the reform movement in Turkey. In contrasting the material coming from the contemporary Muslim world and from Europe, there was a racial undertone in favour of Muslims. He wrote, "Socialism and Peace both demand great moral stamina and spiritual strength which Europe lacks. Almost all the golden pages of the history of this world are chiefly chronicles of the moral victory of Asia." 30 This was connected to his ideas of pan-Islamic nationalism, which he saw as the ultimate political goal of all Muslims (to be achieved through Islamic socialism).

Kidwai remained interested in questions of socialism and Islam until his death in 1937; his last book was on Pan-Islamism and Bolshevism. ${ }^{31}$ It was the first book, however, that became highly influential abroad.

\section{Islamic socialism of H. O. S. Tjokroaminoto}

Kidwai's work on Islam and Socialism was particularly important for Indonesia, because this work was the foremost influence on Indonesia's first modern theorist of Islamic politics: H. Oemar Said Tjokroaminoto. ${ }^{32}$ Born in Ponorogo, East Java, in 1882, Tjokroaminoto was the second of eleven children of a low-level bureaucrat in the Dutch colonial service, but in a family that also included a distinguished lineage of Islamic teachers and leaders. ${ }^{33} \mathrm{He}$ completed his training at the Dutch academy for indigenous civil servants (OSVIA) in 1902, but after three years in a government office he quit to take up a career in trade and industry in the major port city of Surabaya (also studying engineering on the side). In Surabaya, Tjokroaminoto became a hub for radical political activity, taking on as boarders many of Indonesia's future independence leaders, including the first president Sukarno, leaders of the Indonesian Communist Party Musso and Alimin, and Islamist leader of the Darul Islam rebellion S.M. Kartosuwirjo. ${ }^{34}$ Tjokroaminoto also became the first full-time activist of the political-cum-economic organization Sarekat Islam, founded in 1912.

Sarekat Islam quickly grew into Indonesia's first true mass organization. From its roots protecting Muslim traders in a market increasingly dominated by Chinese interests, the organization added programmes such as burial collectives, cooperative stores, and political advocacy. By 1914, it had 360,000 members across Java, and was rapidly expanding outside

\footnotetext{
29 'Kidwai, Shaikh Mushir Husain', p. 23.

${ }^{30}$ Kidwai, Islam and Socialism, p. vii.

${ }^{31}$ M. H. Kidwai, Pan-Islamism and Bolshevism, London, Luzac and Co., [1937?].

${ }^{32}$ For more information on Tjokroaminoto, see the recent study of his impact on national life and legacy today, Tjokroaminoto: Guru Para Pendiri Bangsa, Jakarta KPG bekerjasama dengan Majalah Tempo, 2011, a reprinting of the special commemorative issue of the leading newsmagazine Tempo. For more on Sarekat Islam in general, see A. P. E. Korver, Sarekat Islam, 1912-1916: Opkomst, Bloei en Structuur van Indonesie's Eerste Massabeweging, Amsterdam, Historisch Semenarium van de Universiteit van Amsterdam, 1982.

${ }^{33}$ Hasnul Arifin Melayu, 'Islam and politics in the thought of Tjokroaminoto (1882-1934)', MA Thesis, McGill University, 2000, p. 9-10.

34 Oral history with Harsono Tjokroaminoto, interviewed by Wardiningsih Surjohardjo, Arsip Nasional Republik Indonesia, Koleksi Sejarah Lisan, 1982 \#60 tapes 7, 8, and 9.
} 
of Java, too. ${ }^{35}$ This rose to a peak of over two million in $1919 .{ }^{36}$ Sarekat Islam addressed the needs of not only indigenous traders, but also the peasant classes; it "helped [them] to articulate particular feelings of discontent and, in doing so, gave a means of expression to popular aspirations for material betterment and social emancipation." 37 Tjokroaminoto was crucial in this organization as both an activist and as a figurehead. He travelled around Java making speeches to build support for the organization and edited its mouthpiece, Oetoesan Hindia [Messenger of the Indies], and ran its business branch, Oesaha Setia [Faithful Efforts]. ${ }^{38}$

As Sarekat Islam grew in membership and national importance, it attracted the interest of labour activists, including a communist cell around the Central Javanese city of Semarang, looking for a vehicle for their Marxist ideology. By 1920, the organization was cleft into "Red" (Communist) and "White" (Islamic) factions, with intractably opposed goals for their activism. In October 1921, the national congress discussed a disciplinary action against those members and branches engaged in outside activism (explicitly targeting Communist groups), but this was not put into effect until 1923, when the Communists were expelled from Sarekat Islam and the organization formally became a political party: Partai Sarekat Islam. ${ }^{39}$ The expulsion of the Communists was a major ordeal for Sarekat Islam and for the Indonesian nationalist movement as a whole; after this Sarekat Islam never again dominated nationalist activism, and the organization and its leaders saw their reputations decline. ${ }^{40}$

In 1924, in the immediate wake of this turmoil, Tjokroaminoto published a work in Indonesian, entitled Islam dan Socialisme [Islam and Socialism], pulling heavily from-even plagiarizing-Kidwai's earlier work. ${ }^{41}$ Previous studies of Tjokroaminoto tend to overlook the fact that this work was inspired by - or less generously plagiarized from-a foreign source. ${ }^{42}$ Out of the eleven chapters of Tjokroaminoto's book (the first called "What is Socialism?" and the following ten numbered chapters), only the final chapter contains a majority of original material from Tjokroaminoto; it has three pages of translation among six pages of original material - mostly information about Sarekat Islam as an organization. The other chapters are not only inspired by Kidwai's text, but primarily consist of direct translations of Kidwai. Chapter 5 on "Instances of Islamic Socialism" and Chapter 8 on "Socialistic Government" are the most egregious in this sense; in the former, only five additional words are inserted to connect a point to the Javanese experience, ${ }^{43}$ and in the latter the only addition is to note the

35 T. Shiraishi, An Age in Motion: Popular Radicalism in Java, 1912-1926, Ithaca, Cornell University Press, 1990, p. 77; D. Noer, The Modernist Muslim Movement in Indonesia, 1900-1942, Singapore, Oxford University Press, 1973, p. 320.

${ }^{36}$ PSII dari Tahun ke Tahun (with English Translation), [Jakarta?], Departemen Penerangan dan Propaganda PSII, [1952], p. 5.

${ }^{37}$ Azyumardi Azra, 'The Indies Chinese and the Sarekat Islam: An account of the anti-Chinese riots in colonial Indonesia', Studia Islamika, vol. 1, no. 1, 1994, p. 42.

${ }^{38}$ Melayu, p. 15.

${ }^{39}$ PSII dari Tahun ke Tahun, pp. 6-7.

${ }^{40}$ R. E. Elson, 'Disunity, distance, disregard: The political failure of Islamism in late colonial Indonesia', Studia Islamika, vol. 16, no. 1, 2009, pp. 5-6.

${ }^{41}$ This article cites a recent reprint in current Indonesian spelling: H.O.S. Cokroaminoto, Islam dan Sosialisme, Jakarta, Penerbit Tride, 2003. The original publication does not seem to be extant.

${ }^{42}$ Melayu's thesis includes only an oblique reference to the influence of Kidwai; furthermore, it cites Howard Federspiel's position that Tjokroaminoto's book is a key encapsulation of Islamic political thought in Indonesia at the time, showing no room for this to be a translation (p. 64, n. 7). Valina Singka Subekti, author of Partai Syarikat Islam Indonesia: Kontestasi Politik hingga Konflik Kekuasaan Elite, Jakarta, Yayasan Pustaka Obor Indonesia, 2014, and a descendent from a prominent PSII family, was entirely unaware of Kidwai's text or any foreign influence on Tjokroaminoto. Valina Singka Subekti, meeting with the author, 23 December 2015, Depok, West Java. The only acknowledgement that Tjokroaminoto used Kidwai as a model (although still short of recognizing the nature of the translation) can be found in Jusuf Wibisono, Islam dan Sosialisme, $2^{\text {nd }}$ edition, Jakarta, Pustaka Islam, 2 volumes, 1950, vol I., p. 3.

${ }^{43}$ Cokroaminoto, p. 82. 
Javanese aphorism "Our age is a crazy time!" 44 In many cases, though, Tjokroaminoto paraphrased, abridged, or rearranged Kidwai's work, especially when faced with lengthy quotations from European sources, so this was not a pure, direct translation. In other instances, Tjokroaminoto added significant asides on issues that he believed to be important; the longest of these is an eight-page digression on marriage and divorce in Chapter 3, "The Prophet Muhammad's Socialism," replacing Kidwai's engagement with Rousseau. ${ }^{45}$

On all key theoretical points, Tjokroaminoto agreed with Kidwai. They believed that true Islamic teachings led to a kind of socialism in which all Muslims (and later all humanity) would work together to help one another, uphold the dignity of humanity, and run society in accordance with God's laws. Tjokroaminoto also reached beyond the context of his Indonesian nationalist activism; his book (like Kidwai's) concluded by pointing to pan-Islamism as the ultimate goal of Islamic socialism. ${ }^{46}$ There were a few other instances where Tjokroaminoto starts from Kidwai's ideas but includes a small change, either due to mistranslation or (more likely) continuing theoretical work by Tjokroaminoto. One example of this is a passage from Kidwai that reads: "Islamic laws could sometimes be better interpreted by a poor old woman than by the Khalifa, and the Khalifa in that case had to follow the lead." $" 77$ Tjokroaminoto tweaked this slightly, writing "In cases where a poor old woman gives a better explanation of Islamic laws than the Khalifa, in that case the Khalifa also must follow the majority vote"-an homage to democratic structures. ${ }^{48}$ Tjokroaminoto also showed his Dutch colonial context: he elided or eliminated references to some English orientalists, but inserted Dutch expressions and references to Dutch sources that were not present in Kidwai's work. ${ }^{49}$ As a whole, Tjokroaminoto's departures from the original Kidwai text consist mostly of efforts to make the work speak to Muslims in the 1920s Dutch East Indies (changing the references to more familiar orientalists; adding small sections on topics like marriage that were hotly debated in this community; including information on Sarekat Islam), not changes in substance. Still, the basis of this major opus was clearly in the thought of an Indian Muslim thinker writing in the diaspora, and some of the peculiarities of this context, like the very un-Indonesian phrase "You are building castles in the sky!" (Engkau mendirikan istana dalam udara!), remained in the final text to show just how completely Tjokroaminoto pulled from a foreign source. ${ }^{50}$

For the Sarekat Islam, this text came at a crucial time, when the organization was transitioning from a focus on "relieving the indigenous population from colonial mistreatments" towards "laying out the platform for an independent state of Indonesia based on Islamic precepts," and becoming a more explicitly political group. ${ }^{51}$ The loss of the Communist membership of the Red Sarekat Islam branches, and the growing challenge from secular nationalist groupings, may also have prompted Tjokroaminoto to articulate more clearly his own ideology as regards socioeconomic conditions. Tjokroaminoto was not the only one theorizing about the connection between Islam and socialism at the time. In fact, Haji

\footnotetext{
${ }^{44}$ Cokroaminoto, p. 119.

${ }^{45}$ Cokroaminoto, pp. 52-60. Similar situations are apparent in chapter 7 (pp. 105-115), which inserts two short sections to make the discussion of religion and socialism more theological and devotional, and chapter 9 (pp. 13439), which is addressing a different world situation and so discusses more the Turkish legacy rather than Ottoman glories.

${ }^{46}$ Cokroaminoto, p. 149.

${ }^{47}$ Kidwai, Islam and Socialism, p. iii.

${ }^{48}$ Cokroaminoto, p. 10.

${ }^{49}$ E.g., the omission of the block quote from Gibbon in Chapter 2 (Kidwai, Islam and Socialism, p. 13); the inclusion of Cornellie Huygens (Cokroaminoto, pp. 21-22); and Dutch translations of keywords (Cokroaminoto, p. 33).

${ }^{50}$ Cokroaminoto, p. 141. This expression is nonsensical for Indonesian readers who are not familiar with the English idiom.

51 C. Formichi, Islam and the Making of the Nation: Kartosuwirjo and Political Islam in 20th Century Indonesia, Leiden, KITLV Press, 2012, p. 24.
} 
Muhammad Misbach, a very devout, religiously educated former Sarekat Islam member who broke off with the Red branches, was publishing a rival manifesto, Islamisme dan Kommunisme, serially in 1924 even as the Dutch forced him into exile on the island of Papua. ${ }^{52}$ Despite the fact that Misbach's text also asserted that Islam demanded of all its followers a staunch promotion of economic and social justice - and that it was an original treatise rather than an imported one-it was Tjokroaminoto's work that had the greater impact. The Dutch orientalist C. van Nieuwenhuijze even identified Tjokroaminoto's Islam dan Socialisme as a key text to explain how Indonesian Muslims would behave in an independent state. ${ }^{53}$

It is notable that Tjokroaminoto would choose, at such a critical time of organizational and political upheaval, to wade into the debate relying so heavily on a translation from an Anglophone South Asian source, rather than writing something more original. The tradition of Indonesian authors copying heavily or arguably plagiarizing from foreign texts was common even up through the mid-twentieth century,${ }^{54}$ but Tjokroaminoto's choice to do this when the core identity of this quintessentially Indonesian organization was on the line is a choice in a specific context. Understanding how he came to rely on a foreign text in this way requires some discussion of Tjokroaminoto's intellectual interests as well as his specific life experiences.

\section{Transmission from Kidwai to Tjokroaminoto: The Ahmadiyyah connection}

Tjokroaminoto's interest in South Asian Islam was apparent in various ways, and it serves as an important reminder of the non-Arab influences on Indonesian Islam at the time. Although much of Tjokroaminoto's political activity connected with contemporary movements in the Middle East - especially the continuing debate over the formation of a new caliphate after the collapse of the Ottoman Empire-his intellectual work was more inspired by South Asian sources and Anglophone materials. ${ }^{55}$

Perhaps the strongest proof of Tjokroaminoto's South Asian interest was when he sent his own son to study in north India. Harsono Tjokroaminoto was in India from 1929 to 1930, travelling from Calcutta to Puna, Lahore, and Kashmir. This travel was explicitly directed by his father, with dual purposes. First, his father wanted him to receive additional training in Islam (Harsono had been schooled in Indonesia primarily at Dutch schools). Second, and more importantly, the senior Tjokroaminoto wanted his son to see a different Muslim context, one where Hindus were the majority, and engage in a comparative study of religions. ${ }^{56}$

One recollection that Harsono recounted in an oral history from his time in India was the difference between the two sects of Ahmadiyyah belief, between Qadian and Lahore. The Ahmadiyyah are a controversial group for mainstream Muslims because of the way that they venerate their founder, the nineteenth-century South Asian teacher Mirza Ghulam Ahmad, as an Islamic prophet after Muhammad. ${ }^{57}$ Harsono noted how his family had frequent interactions with an Indian Ahmadi missionary when they were living in Yogyakarta, Central Java. Of course, interacting with an Ahmadi did not mean that they converted to the Ahmadiyyah belief; Harsono stated very clearly that his father did not convert to Ahmadiyyah, just as he did not

\footnotetext{
52 T. Shiraishi, ch. 7 'Islamism and Communism'.

${ }^{53}$ C.A.O. van Nieuwenhuijze, Aspects of Islam in Post-Colonial Indonesia: Five Essays, The Hague: W. van Hoeve, 1958, p. 99, n. 2.

${ }^{54}$ See, for example, the case of Hamka and his book The Sinking of the van der Wijck, recounted in James R. Rush, Hamka's great story: A master writer's vision of Islam for modern Indonesia, Madison, University of Wisconsin Press, 2016, pp. 136-40.

${ }^{55}$ Melayu, pp. 16, 64, 82.

${ }^{56}$ Oral history with Harsono Tjokroaminoto, tapes 5 and 6.

${ }^{57}$ Ahmad Najib Burhani, "Hating the Ahmadiyya: the place of "heretics" in contemporary Indonesian Muslim society’, Contemporary Islam, vol. 8, 2014, pp. 135-36.
} 
convert to Christianity just because he knew several Christian missionaries. ${ }^{58}$ The Ahmadi missionary, Mirza Wali Ahmad Beg, was a major intellectual sparring partner and was most likely the key individual in the transmission of Kidwai's text on Islamic socialism to Indonesia.

Mirza Wali Ahmad Beg of the Lahore Ahmadiyyah arrived on Java with a colleague in 1924, and set up a mission for the movement. ${ }^{59}$ The missionary was Indian in ethnicity, but came to Indonesia from London, where he would have very likely met Mushir Hosain Kidwai since both were active in Islamic organizations. Harsono also reported that his father (and other members of his family) practiced speaking English with Mirza Wali Ahmad Beg, making it possible that the missionary might have presented them with a copy of Kidwai's Islam and Socialism as a discussion text.

This also was not the only English-language text that Tjokroaminoto famously translated in this period, and the other also came from an Ahmadi source. Tjokroaminoto in 1925 began a translation of the Qur'an into Indonesian, working from Maulvi Muhammad Ali's English language translation and commentary (and not the original Arabic - a language in which Tjokroaminoto was not proficient). ${ }^{60}$ Muhammad Ali was a scholar from the Lahore Ahmadiyyah, and the initiative to render his work into Indonesian caused much consternation, even eliciting a fatwa from Rashid Rida (a famous reformist Islamic scholar based in Cairo) against the literal translation of the Qur'an. ${ }^{61}$ This translation effort demonstrates, though, Tjokroaminoto's inclination to translate into Indonesian works in English provided to him by the Ahmadi mission on Java, so it is all the more likely that the Ahmadis may have provided Tjokroaminoto with his copy of Kidwai's text.

Given the current animosity, including violence, towards the Ahmadiyyah community in Indonesia, the strong influence of the Ahmadiyyah on this central stream of Indonesian Islamic thought might be seen as out of line with Indonesian narratives of orthodoxy. ${ }^{62}$ Historically, though, it is part of a well-established trend. The Ahmadiyyah had a very active program of republishing South Asian Islamic thought in Indonesia and often translating it into Indonesian, a program that continued at least through the Indonesian revolution. ${ }^{63}$ The appeal of Ahmadi thought was its emphasis on rationalism, supposedly proving that Islam and the modern world were not incompatible with one another.

Some of the religious ideas held by the Ahmadis may not have been fully understood by their Indonesian interlocutors, since the message was spread in Indonesia using the English language that so few people spoke fluently. ${ }^{64}$ Although the more distinct theological innovations of the Qadiani Ahmadiyyah branch were not and could not be accepted by mainstream Muslim activists in Indonesia, the younger, Western-educated activists influenced by Tjokroaminoto and the Sarekat Islam were also very likely to have engaged with Ahmadiyyah texts in the 1920s and 1930s. Throughout the 1930s, the Ahmadiyyah continued to influence young, Western-educated Islamic thinkers, including the next generation of Islamic socialists. The journal of the Jong Islamieten Bond, a group of Muslim student activists trying to promote a

\footnotetext{
${ }^{58}$ Oral history with Harsono Tjokroaminoto, tape 6, around minute 15.

${ }^{59}$ G.F. Pijper, "De Ahmmadīyah in Indonesia," in Bingkisan budi: een bundel opstellen aan Dr. Philippus Samuel van Ronkel door vrienden en leerlingen aangeboden op zijn tachtigste verjaardag, 1 Augustus 1950, Leiden, A.W. Sijthoff's uitgeversmaatschappij n.v., 1950, p. 251.

${ }^{60}$ Moch Nur Ichwan, 'Differing responses to an Ahmadi translation and exegesis: The Holy Qur'ân in Egypt and Indonesia', Archipel, vol. 62, 2001, p. 147.

${ }^{61}$ Formichi, 30.

${ }^{62}$ Burhani.

${ }^{63}$ See, for example, the book on war in Islam published during the revolution by the Ahmadiyyah Qadian representative in Indonesia: M. Rahmat Ali, Djihad dalam Islam, Jakarta, Neratja Trading Company, 1949. For more on Ahmadi print proselytization, see I. S. Sevea, 'The Ahmadiyya Print Jihad in South and Southeast Asia', in R. M. Feener and T. Sevea (eds.), pp. 134-48.

${ }^{64}$ Moch Nur Ichwan, p. 148.
} 
modern, rational, Islamic future for their country, "was also heavily influenced by the writings of the Ahmadiyah movement in India." ${ }^{65}$ So as to engage in appropriately "scientific" reasoning in their efforts to convert university students into pious Muslims, another organization called the Studenten Islam Studieclub would frequently rely on the Ahmadi exegesis of the Qur'an, which was seen as deploying scientific methodology. ${ }^{66}$ Even during the Indonesian revolution in the 1940s, the Ahmadiyyah received supportive coverage in the Indonesian press for their efforts to spread Islam in Europe. ${ }^{67}$ Thus, the role of the Ahmadiyyah in transmitting Anglophone thought from South Asia to a leading Islamic activist on Java is in line with their broader historical role.

Looking back through Tjokroaminoto's text on Islam dan Socialisme and his wider context, it is clear that South Asian thought was a major inspiration for his theoretical work, and he most likely received this influence through another South Asian intermediary: the Ahmadiyyah movement. Although the Ahmadis were not the only channel for spreading South Asian thought in the Indonesian archipelago - and texts from Indian authors, including Sayyid Ahmad Khan and Muhammad Iqbal, began to circulate in the second decade of the twentieth century in Indonesia ${ }^{68}$ - their ongoing connection with Tjokroaminoto and his intellectual output make them the most probable source to transmit Kidwai's book, the source of Tjokroaminoto's most important theoretical work. Through Tjokroaminoto, in turn, a large number of other Indonesians also became exposed to the idea of Islamic socialism.

\section{Socialism and Islam in Indonesia since Tjokroaminoto}

Because Tjokroaminoto was a personal mentor for a wide range of Indonesia's nationalist leaders, his thinking on Islamic socialism had continuing influence on generations of activists and thinkers. These leaders, in both their published works and in their political efforts, paid homage to the idea of Islamic socialism, but continued to develop the ideas from the foundation laid by Kidwai and Tjokroaminoto.

The stream of thought that moved furthest from Tjokroaminoto's influence was Marxist communism. Although several young leaders of the Indonesian Communist Party (PKI) had boarded with Tjokroaminoto's family in the 1910's, the ideological break between Marxist communism and Sarekat Islam's Islamic socialism had already occurred before Tjokroaminoto published Islam dan Socialisme. Thus, PKI figures like Alimin and Musso looked more towards European theorists of Marxism rather than religious socialists for their ideology. ${ }^{69}$

In the following decades, this led to a sharp break between Marxist communists and pious Muslims of all kinds, including Islamic socialists. As time went on, Marxist Communism (represented in Indonesia by the PKI) stood increasingly in opposition to Islamic groups and sometimes also to Islam as a religion. ${ }^{70}$ This antagonism was in part personal and drawn from experience, but also largely connected with the hostility between PKI-style Communism and religion of any kind, connected with the deeply secular vision of international communism as led by the USSR. Since the 1950s, when the Indonesian Communist Party (PKI) and the Islamic political parties fought tooth-and-nail in parliament and in elections, and especially since the 1960s, when Muslim groups participated in the public witch-hunts and even mass killings

\footnotetext{
${ }^{65}$ M. Laffan, The Makings of Indonesian Islam: Orientalism and the Narration of a Sufi Past, Princeton, Princeton University Press, 2011, p. 218.

${ }^{66}$ Yudi Latif, Indonesian Muslim Intelligentsia and Power, Singapore, ISEAS, 2008, p. 208.

67 "Menjiarkan Agama Islam di Eropah," Merdeka, 17 January 1946.

${ }^{68}$ Moch Nur Ichwan, p. 144.

${ }^{69}$ Alimin, Riwajat Hidup, Jakarta, n.p., 1955.

70 This was especially true from the 1940s. See M.C. Ricklefs, Islamisation and Its Opponents in Java: A Political, Social, Cultural and Religious History, c. 1930 to the Present, Singapore, NUS Press, 2012, chapter 3.
} 
targeting suspected communists, Islam and Marxism have been seen both inside and outside Indonesia as eternal enemies. ${ }^{71}$

Tjokroaminoto's thought (or the thought of Kidwai transmitted through Tjokroaminoto) did have continuing influence on three major groups in Indonesian political life: secular nationalists (epitomized by Sukarno); Islamic politicians (especially those who later led the political party Masjumi); and Islamists (most notably S.M. Kartosuwirjo).

\section{Secular nationalist Sukarno and Tjokroaminoto's legacy}

Perhaps the most famous of Tjokroaminoto's students was Sukarno, later Indonesia's first president. Sukarno boarded with Tjokroaminoto for several years in the 1910's, and even married Tjokroaminoto's daughter (although it is doubtful this marriage was ever consummated). ${ }^{72}$ His famous essay of 1926, "Nationalism, Islam, Marxism," showed some influence from Tjokroaminoto and also a great amount of attention to the intellectual and nationalist developments in India.

First, it is important to note that Sukarno followed Tjokroaminoto to say that "true Islam is socialist in nature." 73 Tjokroaminoto was very clear in his text that Islam is socialist, and it seems that Sukarno took this point from his teacher. Sukarno went several steps further, however. Sukarno emphasized the opposition of Islam to capitalism (built from Islam's rejection of usury) - a point also found in Tjokroaminoto's book. ${ }^{74}$ Sukarno then makes an additional leap to say that Islam must be allied with Marxism. This is a point that Tjokroaminoto roundly rejects; Tjokroaminoto makes it clear in his preface that Marxism (which he sometimes also calls intellectual socialism, or Wetenschappelijk Socialisme in Dutch) is not compatible with Islam because of its fundamental materialism. ${ }^{75}$

It is apparent, though, that both Tjokroaminoto and South Asia were in Sukarno's mind as he wrote this article. At one point he even quotes Tjokroaminoto, to say "It is Amir Mu'awiya [founder of the Ummayyads] who must bear the responsibility for the corruption of the true nature of Islam, which was clearly socialist in character." "76 Sukarno also makes repeated references to the nationalist movement in South Asia, especially to Mohandas K. Gandhi. Sukarno awaited that kind of transformative figure for his own country, not realizing it might be himself: "Perhaps we have as yet no Mahatma, a helmsman who can build and steer the Ship of Unity. Yet I am convinced that eventually the day will come when a Mahatma will appear in our midst." "77 Although Sukarno had also engaged with other Islamic teachers and thinkers, including most notably Ahmad Hassan the leader of Persatuan Islam, ${ }^{78}$ Tjokroaminoto was the teacher with whom he was most associated, and whom he quoted in his famous essay.

Sukarno's thinking on "Nationalism, Islam, and Marxism," as inspired in part by Tjokroaminoto, was incredibly influential on the political direction of the country. In 1960, Sukarno put forward a conception called NASAKOM, an abbreviation of NASionalismeAgama-KOMunisme (Nationalism, Religion, Communism), that became the official

\footnotetext{
${ }^{71}$ See Ricklefs, chapter 3.

72 R.E. Elson, 'Absent at the creation: Islamism's belated, troubled engagement with early Indonesian nationalism', in Anthony Reid and the Study of the Southeast Asian Past, G. Wade and Li Tana (eds.), Singapore, ISEAS, 2012, p. 319.

${ }^{73}$ Soekarno, Nationalism, Islam and Marxism, Karel H. Warouw and Peter D. Weldon (trans.), Ithaca, Modern Indonesia Project, Cornell University, 1970, p. 48.

${ }^{74}$ Soekarno, pp. 50-51; Cokroaminoto, p. 12.

${ }^{75}$ Cokroaminoto, pp. 22-23.

${ }^{76}$ Soekarno, p. 47; Cokroaminoto, 130; Kidwai, Islam and Socialism, 67.

${ }^{77}$ Soekarno, pp. 36-37. Gandhi is cited again on p. 40.

${ }^{78}$ See his 'Surat-surat dari Endeh' in Soekarno, Dibawah bandera Revolusi, Yogyakarta: Media Pressindo and Yayasan Bung Karno, 2015, pp. 365-384.
} 
government platform. ${ }^{79}$ Although this deviated substantially from Tjokroaminoto's intellectual position, Sukarno was still able to use his teacher's text and especially his religious pedigree from studying with Tjokroaminoto to promote this nebulous slogan. ${ }^{80}$

\section{Tjokroaminoto's legacy in Islamic politics}

In Islamic politics, a major political bloc of Islamic socialist politicians continued and further developed the legacy of Tjokroaminoto and Kidwai. This bloc was led by the party that produced the most Prime Ministers in the period of Indonesia's liberal democracy, and the party predicted to win the 1955 elections (it actually came in second), Masjumi. ${ }^{81}$

George Kahin observed that, in the immediate aftermath of the Indonesian Revolution, the political leaders of every major party followed some variant of socialism. ${ }^{82}$ The Islamic parties were no exception, but they framed themselves as Religious Socialists or Islamic Socialists, carrying the banner of religiously-inspired social thought rather than merely evolving from Western models. ${ }^{83}$ The leading lights of the this movement were men whose names continue to be venerated in Indonesian Islamic politics until today: Sukiman Wirjosandjojo, Mohamad Roem, Mohammad Natsir, Jusuf Wibisono, Prawoto Mangkusasmito, Burhanuddin Harahap, Sjafruddin Prawiranegara, and Abu Hanifah. Three of them became prime minister of Indonesia, and the others held high cabinet positions like finance, foreign affairs, education, and home affairs. These men explicitly built on the foundation of Tjokroaminoto's book to describe their vision for the country's future, citing him in their own theoretical works on Islam and socialism and building their new party on their organization experiences in Tjokroaminoto's organization and successor groups.

Many of the leaders came out of Partai Sarekat Islam Indonesia, the successor to Tjokroaminoto's Sarekat Islam. Sukiman, the most senior of the group, had in fact worked directly with Tjokroaminoto after returning from his education in the Netherlands. Roem and Wibisono played more minor roles in PSII and off-shoot factions in the 1930s as Islamic politics became more heavily contested. Many future Masjumi leaders (including Natsir, Roem, Wibisono, and Prawoto) also took part in the student organization Jong Islamieten Bond, ${ }^{84}$ or the corollary organization for university students, Studenten Islam Studieclub (including Wibisono, Roem as founders; Prawoto and Burhanuddin Harahap as members). ${ }^{85}$ Both of these groups were also heavily influenced by South Asian thought through the Ahmadiyyah. ${ }^{86}$

\footnotetext{
${ }^{79}$ T. Friend, Indonesian Destinies, Cambridge, Massachusetts, Belknap Press, 2003, p. 82.

${ }^{80}$ B. R. O'G. Anderson, 'The Javanese idea of power', in Language and Power: Exploring Political Cultures in Indonesia, Jakarta, Equinox, 2009, pp. 29-30.

${ }^{81}$ Partai Sarekat Islam Indonesia, the direct heir of Tjokroaminoto's movement, broke away from Masjumi in 1947 and also carried on the legacy of Islamic socialism in politics, but it was less impactful on the national scene at the time. On the reestablishment of PSII, see K. W. Fogg, 'The missing Minister of Religion and the PSII: A contextual biography of K. H. Ahmad Azhary', Studia Islamika, vol. 20, no. 1, 2013, pp. 35-57.

${ }^{82}$ G. McT. Kahin, 'The impact of American foreign policy', in Democracy in Indonesia: 1950s and 1990 s, D. Bourchier and J. Legge (eds.), Clayton, Victoria, Centre of Southeast Asian Studies, Monash University, 1994, p. 64.

${ }^{83}$ Kahin probably coined this phrase in his classic work on the revolution, G. McT. Kahin, Nationalism and Revolution in Indonesia, Ithaca, Cornell University Press, 1952, pp. 156-58. It was a title later embraced by the group themselves, as evident in Abu Hanifah, Tales of a Revolution, Sydney, Angus and Robertson, 1972, pp. 161-62.

${ }^{84}$ Yudi Latif, pp. 204-206.

${ }^{85}$ Oral history of Burhanuddin Harahap, interviewed by J.R. Caniago, Arsip Nasional Republik Indonesia, Koleksi Sejarah Lisan, 1980 \#1, tape 1; Yudi Latif, pp. 207-208.

${ }^{86}$ Moch Nur Ichwan, pp. 156-57.
} 
Once coming into leadership in national politics during the Indonesian revolution (1945-49), this new wave of Islamic socialists wrote tracts on their ideology fit for the new age. The most thorough of the theoretical treatments of the question of Islam and socialism during this period came from Jusuf Wibisono, in his book Islam dan Sosialisme [Islam and Socialism]. ${ }^{87}$ This work had been first serialized in the Masjumi-aligned magazine Hikmah from 1949, but it was soon compiled into a book. Jusuf Wibisono's Islam dan Sosialisme sold some 10,000 copies when it first came out; if the publisher can be believed, this many were sold in the first month. ${ }^{88}$

This was placed very consciously in the tradition of Tjokroaminoto. Jusuf Wibisono recognized in the very first line of his text that he was building on the work of Tjokroaminoto, and even recognized further down that Tjokroaminoto had used Kidwai as a model (although Wibisono does not go so far as to mention the apparent plagiarism in Tjokroaminoto's text). ${ }^{89}$ The content of Jusuf Wibisono's book was a major evolution from the thinking of Tjokroaminoto himself-more of an evolution than between Kidwai and Tjokroaminoto, but perhaps on par with the level of innovation between Tjokroaminoto and Sukarno. Jusuf Wibisono again wanted to derive socialist ideas from Islamic sources, and so he looked to the time of the Prophet Muhammad and the companions to find scriptural references and precedent practices on which to base a modern socialist model. Like their predecessors, the new Islamic socialists were conscious of developments in European material socialism, most notably from Dutch authors; given that they were writing at the start of the Cold War, they spent more time on comparison with Marxist socialism than earlier authors. Still, they rejected that ideology in favour of one framed around Islamic scripture. One can see this clearly when Wibisono lists twenty-some types of socialism, from utopianism to syndicalism to Christian socialism, only to culminate in Islamic socialism as the final and most perfect model..$^{90}$

The Islamic socialists of Masjumi believed in a socio-economic program that combined religious beliefs and social justice priorities. The Islamic Socialists wrote that Islam had both the strong moral principles to organize society and the deep compassion for the disadvantaged that were necessary for a downtrodden society as found in Indonesia. ${ }^{91}$ This new generation wanted to meet people's material needs, but also go beyond this, as Sjafruddin Prawiranegara explained: "While admitting the fact that human beings need to eat, drink, marry, and have a home to live, that does not necessarily mean that human beings live only to eat, drink, marry, and have homes." 92 Practicing Islam was certainly the ends but also the means to achieve their political vision for Indonesian society; if the working class lived and struggled in accordance with the teachings of the Qur'an it would improve their fate. ${ }^{93}$

The Islamic Socialists' platform mirrored standard socialist programmes but with some distinct and religiously grounded limitations. Their programme for Masjumi included guaranteeing the life and livelihood of the Indonesian masses. They promoted the obligation for employers to provide sick leave, pensions, and "social payments" to employees to support the economic and social welfare of workers, although unlike most socialists they limited the right to strike. ${ }^{94}$ While upholding the sanctity of private property in Islam, Sjafruddin made it

\footnotetext{
${ }^{87}$ Wibisono, Islam dan Sosialisme.

${ }^{88}$ Panitia Mu’tamar Masjumi ke-V, Indonesia dalam Pembangunan, Jakarta, Alvaco, 1951, p. 54, in an advertisement for Penerbit SINAR ILMU Djakarta.

${ }^{89}$ Wibisono, vol. I, p. 3.

${ }^{90}$ Wibisono, vol. I, p. 6-9.

91 Oral history with Sjafruddin Prawiranegara, interviewed by J.R. Caniago, Arsip Nasional Republik Indonesia, Koleksi Sejarah Lisan, 1979 \#6, tape 3; Abu Hanifah, Tales of a Revolution, pp. 64, 69, 161-62, 188, 213.

${ }^{92}$ Sjafruddin Prawiranegara, Politik dan Revolusi Kita, $2^{\text {nd }}$ edition, Medan, Andalas, [1948?], pp. 19-20.

${ }^{93}$ Wibisono, Islam dan Sosialisme, vol. II, 29.

${ }^{94}$ Pedoman Perjuangan Masjumi, $2^{\text {nd }}$ edition, Jakarta, Pimpinan Partai Masjumi Bagian Keuangan, 1955, pp. 68-69, 55; Abu Hanifah, Kita Berdjoang: Goebahan Kultur Politis, Jakarta, Merdeka, 1946, p. 60.
} 
clear that Islamic socialists were open to nationalization of industries, but only certain ones that were truly necessary for the good of the people and only after appropriate consultations. ${ }^{95}$ They also wanted to limit the excesses of capitalism and to "fight for the right to live fully for our common people, called the labourers or farmers," aiming for a time when each individual in society would have "Economic Freedom" and not just national or religious freedom. ${ }^{96}$

In this platform, the Islamic Socialists had certain commonalities with the leftist movement more broadly. In the words of Sjafruddin Prawiranegara,

Social justice, which is one of the goals and aspirations of the ideology of Marxism, is also a guideline for Islam. Progress and high standards of living for the poor community, the oppressed community and those oppressed by all the harshness of the capitalists, these are also aspirations of Islam. It is an obligation for all Muslims to help and aid the weak, poor, and oppressed. Islam also, like Marxism, recognizes the presence of groups or classes within society. ${ }^{97}$

At the same time, the Islamic Socialists were uncompromising in their utter rejection of any overall compatibility between Marxism and Islam. No topic gets so much attention in the writings of Islamic Socialists as the rejection of Marxist Communism. ${ }^{98}$ The Masjumi authors rooted a small part of their rejection in "conflicting understandings on methods and guidelines." $" 99$ The greater issue, and the one that took most of the attention, was the atheism of Marx and Marxist socialism or communism; this was something that the Islamic politicians could not brook. Railing against atheism and the false ideology of religion as "opiate of the masses," Abu Hanifah, Jusuf Wibisono, and Sjafruddin Prawiranegara all insisted in their revolutionary writings that no Muslim (or Christian, for that matter) could truly be a Communist. ${ }^{100}$

Several leaders of Masjumi also came to embrace the kind of pan-Islamic anti-Westernism that can be found in Kidwai and Tjokroaminoto. Sjafruddin Prawiranegara, writing from the forests of Sumatra where he led the Indonesian "Emergency Government" in 1949, foresaw a coming Third World War between capitalism and communism, both morally bankrupt, in which the victor would be "the third great moral force: Islam!"101 This sounds similar to the Islamic triumphalism of Kidwai, contrasted with the moral weakness of the West. Later in life, both Natsir and Roem became involved in efforts to unite the Muslim world, ${ }^{102}$ as well, reminiscent of the pan-Islamic note that both Tjokroaminoto and Kidwai used to conclude.

\footnotetext{
${ }^{95}$ Prawiranegara, Politik dan Revolusi Kita, p. 42.

${ }^{96}$ Abu Hanifah, Kita Berdjoang, p. 46.

${ }^{97}$ Sj. Prawiranegara, Islam dalam Pergolakan Dunia, $2^{\text {nd }}$ edition, Bandung: Al-Ma'arif, 1950, p. 13; Jusuf
} Wibisono wrote almost exactly the same points in Islam and Sosialisme, vol. II, pp. 23-24.

${ }^{98}$ Prawiranegara, Politik dan Revolusi Kita, pp. 10-15, 39-48; Wibisono, vol. II, pp. 22-47; Abu Hanifah, Soal Agama dalam Negara Modern, $2^{\text {nd }}$ edition, Jakarta, Tintamas, 1950, pp. 28-45. This was also a major campaign point for Masjumi in the 1950s; see R. Madinier, 'Lawan dan Kawan (Friends and Foes): Indonesian Islam and communism during the Cold War (1945-1960)', in Connecting Histories: Decolonization and the Cold War in Southeast Asia, 1945-1962, C. E. Goscha and C. F. Ostermann (eds.), Stanford, Stanford University Press, 2009, p. 360 .

${ }^{99}$ Wibisono, vol. II, p. 30.

${ }^{100}$ Wibisono, vol. II, p. 11; Abu Hanifah, Kita Berdjoang, pp. 154-155; Prawiranegara, Politik dan Revolusi Kita, p. 10.

${ }^{101}$ Prawiranegara, Islam dalam Pergolakan Dunia, p. 10. This was probably not directly from the influence of Tjokroaminoto and Kidwai's work, but rather in the general zeitgeist of the postwar era; similar sentiments were expressed in this era by Kartosuwirjo (B.J. Boland, The Struggle of Islam in Modern Indonesia, The Hague, Nijhoff, 1971, p. 61), and even by the head of the Arab League, Abdurrahman Azzam (A. 'Azzam, The Eternal Message of Muhammad, trans. C. E. Farah, London, Quartet, 1979, pp. xii, 278-79).

102 A. R. Kahin, Islam, Nationalism and Democracy: A Political Biography of Mohammad Natsir, Singapore, NUS Press, 2012, pp. 181-182; Mohamad Roem, 'Ikut serta dalam peringatan tahun pertama Revolusi Islam Iran yang gemilang', in Bunga Rampai dari Sejarah, Jakarta, Bulan Bintang, 1988, vol. IV, 123-33. 
Although Masjumi as a party was forcibly disbanded by Sukarno in 1960, Islamic politicians until today continue to claim its legacy. ${ }^{103}$ In this way, the Islamic socialist thought of Kidwai and Tjokroaminoto, as developed by the Islamic socialist leaders of the early independence period, continues to shape Indonesian politics.

\section{Indonesian Islamism and Islamic socialism}

The most well-known Islamist of Indonesia in the twentieth century was S. M. Kartosuwirjo, who led a rebellion called Darul Islam from 1949 until 1962, seeking to re-establish Indonesia as an explicitly Islamic state. Kartosuwirjo was also heavily influenced by Tjokroaminoto, and the impact of Tjokroaminoto's socialist thought can be seen in Kartosuwirjo's movement.

Kartosuwirjo, like Sukarno and others, had boarded briefly with Tjokroaminoto's family as a young man, ${ }^{104}$ but he stayed committed to the Sarekat Islam and its successor organizations (the Partai Sarekat Islam and later Partai Sarekat Islam Indonesia) through the end of the 1930s. He also co-edited the Sarekat Islam-affiliated newspaper in Jakarta, and played a mentoring role for Tjokroaminoto's son, Harsono Tjokroaminoto. ${ }^{105}$ Although he was at odds with the party leadership at the end of the colonial period because of his unbending opposition to any form of working with the Dutch colonialists, Kartosuwirjo remained committed to Tjokroaminoto's vision of Islamic nationalism. ${ }^{106}$ This included aspects of Tjokroaminoto's Islamic socialism.

When Kartosuwirjo went into rebellion against the Republic of Indonesia in 1949, setting up his own "Islamic State of Indonesia," he incorporated elements of Islamic socialism in the areas he controlled. The constitution of his so-called state, called the "Qanun" to emphasize the Islamic bent, "sanctioned the right for all citizens to work and to maintain appropriate standards of living. It also established the principle of mutual aid for matters pertaining to the life and livelihood of the people, and the right-duty to pursue an education, which would be facilitated by the government's establishment of a system of Islamic schooling."107 Much like the Masjumi programme, Kartosuwirjo also considered how to exploit natural resources in a way that would bring the widest possible benefit to Muslim society as a whole.

Indeed, in his political outlook Kartosuwirjo shared much in common with the Islamic socialists of Masjumi, who were his contemporaries and formerly his colleagues in PSII activism. Kartosuwirjo even held regional positions in Masjumi before going into rebellion and held an ambiguous position as regards the party even after breaking with the Indonesian state. ${ }^{108}$ Like the Masjumi activists, Kartosuwirjo evolved his Islamic socialism from the writings of Tjokroaminoto and with the additional awareness (although not necessarily acceptance) of developments in European material socialism. For Kartosuwirjo, this included the German Social Democrats of the late nineteenth century and the writings of Rosa Luxemburg. ${ }^{109}$ As time went on, however, he became more dogmatically Islamic in his thinking and increasingly presented himself and his political positions using Arabic terms and other religious trappings. ${ }^{110}$ Although forgotten by outsiders in the face of the violence that the

${ }^{103}$ G. Fealy and B. Platzdasch.

${ }^{104}$ Oral history with Harsono Tjokroaminoto, tape 8.

105 Oral history with Harsono Tjokroaminoto, tape 12.

${ }^{106}$ Formichi, pp. 40, 43, 46.

${ }^{107}$ Formichi, p. 125.

${ }^{108}$ D. Noer, Partai Islam di Pentas Nasional 1945-1965, Jakarta, Grafiti Pers, 1987, pp. 100-101; R. Madinier, Islam and Politics in Indonesia: The Masyumi Party between Democracy and Integralism, Jeremy Desmond (trans.), Singapore, NUS Press, 2015, pp. 155-79.

${ }_{109}$ H. H. Dengel, Darul Islam - NII dan Kartosuwirjo: Langkah Perwujudan Angan-Angan yang Gagal, Jakarta, Pustaka Sinar Harapan, 2011, p. 33, n. 56.

${ }^{110}$ Noer, Partai Islam di Pentas Nasional, p. 182. 
rebellion wrought for over a decade, the Islamic socialism of the Darul Islam movement has been remembered by sympathizers and those who sought to carry on the legacy of an Islamic state.

Darul Islam remains relevant today because it was the forefather of contemporary Islamist movements in Indonesia. Most famously, it was both an inspiration for and a direct influence on the violent Islamist groups who engaged in terrorism in the early twenty-first century. ${ }^{111}$ Thus, Tjokroaminoto's legacy of Islamic socialism continues to have an impact on Indonesian Islamism up to the present.

\section{Conclusion}

This study of Islamic socialism is important for two reasons. First, the circulation of this idea from South Asian authors through an Indonesian language version to Southeast Asian audiences shows the alternative trajectories of Islamic intellectual history in this period. The ideology travelled from South Asia to Southeast Asia via London and was transmitted, most likely, by the minority Ahmadiyyah community. This provenance for such a major text challenges the unthinking focus on orthodoxy and Middle Eastern origins in most Islamic intellectual history.

All the same, fate of the text does not feed into theories of a conscious, public redrawing of intellectual lines in the early twentieth century, either. Nile Green's assertion that a new conception of the "Muslim World" was growing ever closer and incorporating Europe in a prominent place within the new religious geography falls down in this case. The very thorough domestication of the Kidwai text by Tjokroaminoto fundamentally erased both the South Asian author and the London publication of the original work - the erasure allowed the text to be framed as appropriate for Muslims but designed specifically for Indonesia. Indeed, despite the generally positive attitude that Islamic politicians in mid-century Indonesia had of the West, ${ }^{112}$ Islamic socialism was framed in contradistinction to European socialist thought, and its Indonesian iterations were drawn from scriptural inspirations.

The fact that nationalist frames for this intellectual trajectory won out over pan-Islamic ones may have allowed this vision of Islamic socialism to have a greater impact on Indonesia's intellectual history. Just since Indonesia's independence, Tjokroaminoto's text has been reprinted in 1946, ${ }^{113} 1950,{ }^{114} 1954,{ }^{115} 1963,{ }^{116} 2003,{ }^{117} 2008,{ }^{118}$ and $2010,{ }^{119}$ showing its longevity and continuing interest to Indonesian audiences. Kidwai's English text, by contrast, has not been reprinted, meaning that far more have read his work in its Indonesian adaptation than in the original form. Tjokroaminoto's book also had an ongoing influence on the leading politicians of the immediate post-independence era, among many other political and theoretical trends. The major impact of this idea on Indonesia's intellectual history is the second reason why studying Islamic socialism is so important. Although leftism has been cast aside in Indonesian history since the 1965 alleged coup blamed on the Indonesian Communist Party, a

${ }^{111}$ Q. Temby, 'Imagining an Islamic State in Indonesia: From Darul Islam to Jemaah Islamiyah', Indonesia, vol. 89, April 2010, pp. 1-36.

112 Madinier, Islam and Politics in Indonesia, pp. 25-28.

${ }^{113}$ Umar Said Tjokroaminoto, Islam dan Socialisme, Padang Panjang, n.p., 1946.

${ }^{114}$ Umar Said Tjokroaminoto, Islam dan Socialisme, $4^{\text {th }}$ edition, Jakarta, Bulan Bintang, 1950.

${ }^{115}$ Umar Said Tjokroaminoto, Islam dan Socialisme, $5^{\text {th }}$ edition, Jakarta, Bulan Bintang, 1954.

${ }^{116}$ Umar Said Tjokroaminoto, Islam dan Sosialisme, Jakarta, Lembaga Penggali dan Penghimpunan Sedjarah Indonesia, 1963.

${ }^{117}$ H.O.S. Cokroaminoto, Islam dan Sosialisme, Jakarta: Penerbit Tride, 2003.

${ }^{118}$ Umar Said Tjokroaminoto, Islam dan Sosialisme, Bandung, Sega Asri, 2008.

${ }^{119}$ Umar Said Tjokroaminoto, Islam dan Sosialisme, $2^{\text {nd }}$ edition, Bandung, Sega Asri, 2008. 
particular kind of socialism was a leading political idea for several decades and a jumping off point for both secular and religious political thinkers moving forward. 